\title{
Traduzir o radicalmente outro: rumo a uma epistemologia do traduzir
}

\author{
Paulo Oliveira*
}

\section{Fluxo, Episteme}

Tradução é movimento. E envolvimento. Esse último aspecto tem sido frequentemente tratado por abordagens tributárias da psicanálise, privilegiando as dimensões subjetivas do ato tradutório. De minha parte, tenho remetido à tradição hermenêutica que vê no sujeito interpretante uma condição de possibilidade desse ato, ao explorar os pontos de contato dessa tradição com a teoria da linguagem do Wittgenstein tardio. Já o movimento, mote aglutinador das contribuições aqui reunidas, tem sido tradicionalmente tratado sob a égide do transporte, pressupondo conteúdos estáveis a serem levados de um lado a outro (metáfora do vagão de cargas). Na pósmodernidade, o foco deslocou-se para o fluxo contínuo, do qual o conceito derridiano de différance é um ícone. Tal fluxo certamente está em jogo na imagem de capa do livro Vozes da tradução (Esteves; Veras, 2015), com mais destaque em versão preliminar, onde se percebem vários contrastes, como fluxo e contra fluxo, obstáculos, direção geral do movimento, pedras e seixos no leito do riacho etc. (Figura 1). Na versão impressa, o fluxo só é evidente na contracapa e a relação entre os detalhes esvanece.

\footnotetext{
${ }^{*}$ Universidade Estadual de Campinas.
} 


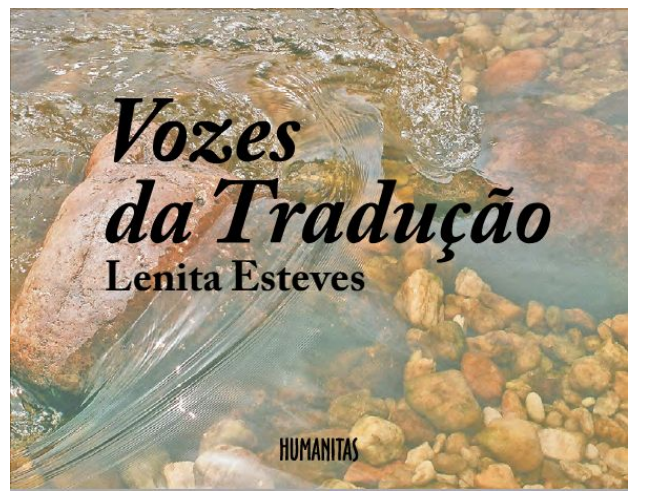

Figura 1: Fluxo

A mim interessa não apenas o fluxo em si, mas sobretudo o jogo entre o fluxo e seus determinantes, relação antes dialética que dualista. À maneira de Guimarães Rosa em Aletria e hermenêutica (prefácio a Tutaméia), poderíamos perguntar, sobre a cachoeira: tirando a água, fica o quê? Barranco. Invertendo os termos: tirando o barranco, fica o quê? - Poça d'água, lago, lagoa (no plano, com margens etc.). Tanto a tradição como seu questionamento pós-moderno privilegiam um dos polos da tensão entre estabilidade e movimento, deixando de investigar a fundo a relação fundamental entre eles. A filosofia tardia de Wittgenstein pode nos ajudar nesse ponto, notadamente em suas implicações epistêmicas, tão radicais quanto pouco exploradas por um público mais amplo - embora alguns estudiosos considerem Da certeza (Wittgenstein, 2004 [DC]) a mais importante contribuição à epistemologia desde Kant (cf. Moyal-Sharrock; Brenner, 2007). ${ }^{1}$ A metáfora do leito do rio (DC, §§ 93-99), intimamente ligada à da dobradiça que permite à porta girar (DC, $\S \S 341,655)$, sintetiza bem essa perspectiva. Ao cotejar as duas imagens, Joachim Schulte (2007, p. 70) sumariza: "a parte fixa segura a parte mais obviamente ativa, ao passo que a parte móvel dá à parte imóvel a sua função". ${ }^{2} \mathrm{O}$ próprio Wittgenstein regis-

\footnotetext{
${ }^{1}$ Na literatura de pesquisa wittgensteiniana, é usual indicar obra/sigla e trecho/parágrafo numerado, de modo independente da edição consultada. Onde possível, procuro manter essa praxe, de modo complementar ao sistema de referências desta publicação.

2 Traduções que não constem das referências bibliográficas são de minha responsabilidade.
} 
tra, contudo, que os papeis podem mudar, o fixo tornando-se móvel e o que era móvel sedimentando-se (DC, § 96). Mesmo assim, precisamos distinguir "entre o movimento das águas no leito do rio e o deslocamento desse; apesar de não haver uma separação clara entre ambos" (DC, § 97). Fazer essa distinção e explorar suas implicações é parte fundamental da discussão epistêmica, que diz respeito à sustentação de nossos conceitos e daquilo que tratamos como conhecimento. No prefácio às Investigações Filosóficas, o autor confessa não ter conseguido escrever um livro como queria, no qual o argumento pudesse "progredir de um objeto a outro numa sequência natural e sem lacunas". Esse aparente fracasso teria origem em sua própria forma de pensar:

\begin{abstract}
meus pensamentos logo se enfraqueciam quando tentava, contra sua tendência natural, forçá-los em uma única direção. - E isso certamente coincidia com a natureza da própria investigação. Esta, com efeito, obriga-nos a explorar um vasto domínio do pensamento em várias direções. [...] Os mesmos pontos, ou quase os mesmos, foram incessantemente retomados por caminhos diferentes, sugerindo sempre novas imagens. (Wittgenstein 2009, p. 3-4 [IF])
\end{abstract}

Muitos comentadores enfatizam a aparente confissão de fracasso, desconsiderando a observação, fundamental, de que a falta de linearidade (co-)responde à "natureza da própria investigação". Ora, se o método responde à natureza do objeto, ele é adequado, por mais que isso contrarie os cânones vigentes. O que permite a intersecção entre dispersão aparente e aprofundamento por retomada, ou repetição (com mudança), é o fato de que a discussão remete às bases do funcionamento de nossos jogos de linguagem, à forma como o próprio conhecimento se constitui - à episteme, em suma. Numa observação tardia (11/05/1947), recolhida em Cultura e valor (Wittgenstein 2006, p. 71 [CV]), o filósofo registra: “Continua-se esquecendo de ir aos fundamentos. Os pontos de interrogação não são colocados fundo o bastante". Ir mais fundo nas questões significa, num vocabulário kantiano, inquirir sobre as condições de possibilidade de nossos conceitos. Em nosso caso específico: o que é necessário para que possamos falar em tradução? 
II. Ato

Um aspecto marcante da filosofia tardia de Wittgenstein é seu caráter eminentemente pragmático, seu compromisso com a ação - aquilo que fazemos com ou por meio da linguagem. Wittgenstein não raro aludia a uma passagem do Fausto de Goethe: "no início, era o ato" (cf. DC, § 402). ${ }^{3}$ No trecho em questão, o protagonista começar a traduzir o Evangelho segundo São João:

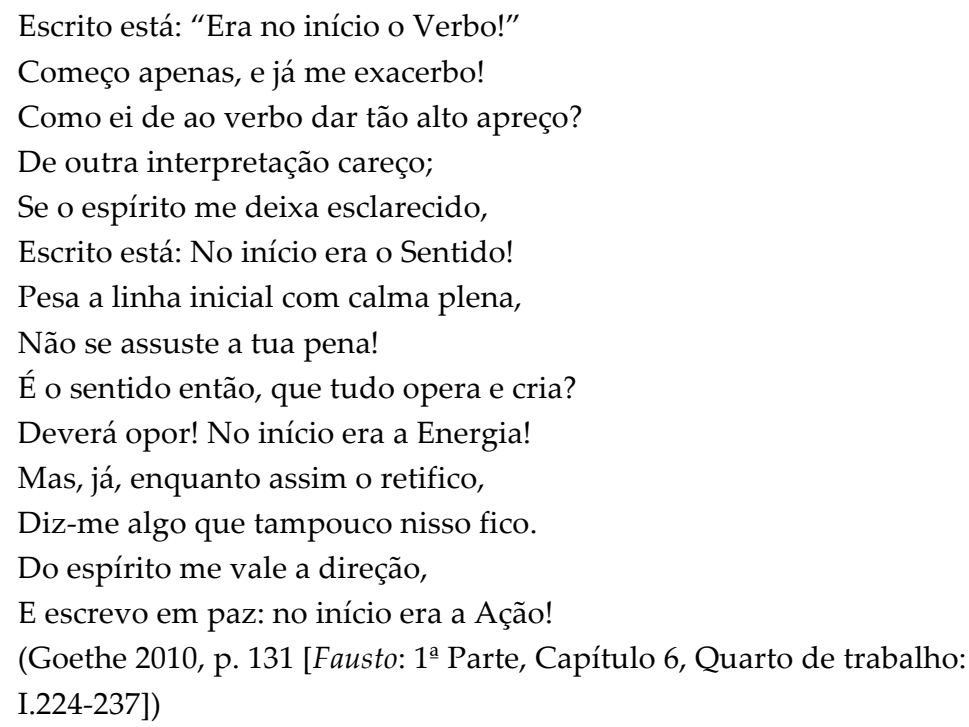

Na bela tradução de Jenny Klabin Segal, atenta a ritmo, métrica e rima, no início era a ação. Para nossa discussão, o termo alemão Tat pode ser vertido por ato. Importa aqui perguntar, por exemplo, até que ponto podemos dizer que os diferentes atos de fala propostos por Austin correspondem a características universais, independentes de língua e cultura, como procurou demonstrar uma corrente majoritária na pragmática linguística, ou se refletem antes fenômenos êmicos, internos e irredutivelmente específicos de cada comunidade cultural. Voltarei ao tema mais adiante.

\footnotetext{
${ }^{3}$ Ver também DC, § 204: “é nosso agir o que fica na base do jogo de linguagem"; IF, §: “[...] (Palavras também são atos)".
} 


\section{Formas(s) de vida}

Por ora, repassemos a noção wittgensteiniana de forma(s) de vida e indaguemos sobre suas implicações para traduções que envolvam o radicalmente outro, tendo em mente que "imaginar uma língua significa imaginar uma forma de vida" (IF, § 19). Helena Martins (2014) já abordou o tópico, remetendo a questões tradutórias e utilizando a expressão alteridade radical (p. 227, 228) para evocar os experimentos de pensamento em que Wittgenstein nos convida a imaginar contatos com tribos estranhas, marcianos etc. Segundo Martins (p. 224-229), as interpretações mais comuns da expressão forma de vida tentam "aplacar sua inquietude", num "esforço para apreendê-la conceitualmente", com "dois vetores principais: um mais universalizante, outro mais relativizante" (p. 224). Na primeira linha, dá-se ênfase às diferenças biológicas entre seres humanos e "outras espécies naturais (cães, leões etc.)". Na segunda, prevalece a sugestão de que "Wittgenstein tinha em mente a natureza social da linguagem, sua dependência de práticas e convenções culturais", enfatizando "o caráter irredutivelmente múltiplo das formas de vida humana" (p. 225). Tal linha interpretativa acomodaria "a possibilidade de [as línguas e culturas] serem afinal incomensuráveis e [...] intraduzíveis entre si", abrindo espaço para inferirmos a existência de "fronteiras histórico-antropológicas insuperáveis". A visada wittgensteiniana permitiria resistir simultaneamente aos dois polos da dicotomia universalismo vs. relativismo, tendo como alternativa uma abordagem perspectivista. Concordo em linhas gerais com o argumento, sobretudo no que mobiliza a leitura de Da certeza feita por Bento Prado Jr. (2004), largamente compatível com a discussão contemporânea (cf. Rhees 2003; Moyal-Sharrock 2007; Moyal-Sharrock; Brenner 2007, dentre outros). Fundamental é aqui o conceito de imagem de mundo, aquele substrato de "certezas não cognitivas, subterrâneas e silenciosas", porém coercitivas (Martins, 2014, p. 226), aquilo que "precede a alternativa entre o verdadeiro e o falso e abre espaço para seu advento" (Prado Jr. 2004, p. 157; cf. DC, § 97). Definido o ponto de vista, colocam-se algumas perguntas que sintetizam amplos programas de trabalho: 


\begin{abstract}
[S]e imaginar uma língua é imaginar uma forma de vida e se entendemos a forma de vida com as cores perspectivistas aqui insinuadas, então que impacto tem isso sobre [1] o modo como podemos pensar a atividade da tradução - e [2] sobre sua capacidade de realizar o devir das línguas? Dada a relação indissolúvel entre linguagem e forma de vida, como e em que medida isso equivale a dizer que a tradução entre línguas é também tradução de ou entre formas de vida (tanto nos limites quanto nas possibilidades)? (Martins 2014, p. 228; numeração entre chaves acrescida)
\end{abstract}

Martins prioriza o segundo ponto em destaque, retomando um mote de Blanchot que deu início a seu texto. Meu interesse, por contraste, recai sobre o primeiro: a forma como entendemos o ato tradutório sob a perspectiva em tela. Por esse ângulo, cumpre rever o escopo da própria noção de (in)comensurabilidade que está na base do discurso corrente sobre a (in)traduzibilidade, tópico que retomarei mais adiante. A necessidade de readequar nosso conceito de tradução, para torná-lo compatível com as práticas reais nele subsumidas, advém exatamente daqueles aspectos etnológicos, relativos ao "caráter irredutivelmente múltiplo das formas de vida humana" privilegiados pela segunda vertente interpretativa. Minha leitura admite um certo relativismo cultural, mas não epistêmico, por aterse a uma epistemologia do uso como proposta por Arley Moreno (2005, 2012, 2013, dentre outros) na confluência de Wittgenstein com o epistemólogo francês Gilles Gaston Granger. Uma diferença adicional diz respeito ao ponto de aplicação. Martins (2012, p. 145) questiona a aplicabilidade de "nosso" conceito de tradução a culturas radicalmente diversas como, por exemplo, a ameríndia (tal como caracterizada por Viveiros de Castro). De fato, se a forma de vida é outra, nada garante que "nosso" conceito de tradução faça sentido nesse outro contexto. Minha indagação é sobre o escopo daquilo que possamos considerar esse nosso conceito de tradução: ele dá conta do que fazemos na prática real que chamamos de traduzir? Mais ainda: ele permite a passagem do eu para o outro, de uma para outra(s) forma(s) de vida?

\title{
IV. Hermenêutica
}

Qual é a relação entre o eu e o outro? O escritor suíço Peter Bichsel escreve sobre seu país e a sensação de "estar em casa". Fala da possibilidade de 
saber o que é regra ou exceção, de diferenciar com certeza quem é tímido ou cosmopolita, de ter saudade (do que é conhecido); do que agrada ou incomoda, e conclui: “O que me alegra ou irrita, o que me causa dificuldade ou dá prazer, o que me ocupa, diz respeito quase exclusivamente à Suíça e aos suíços. É isso o que quero dizer quando afirmo: 'Sou suíço'" (in Eichheim et al. 2011, p. 251).4 Para além do aparente provincianismo, o texto de Bichsel coloca a questão fundamental acerca do ponto de vista, do nosso interesse e, mais ainda, da possibilidade de situarmos e/ou entendermos o que é nosso ou alheio. Num outro registro, é exatamente disso que trata Hans-Georg Gadamer (1997) em sua Hermenêutica clássica e filosófica, ao explicitar uma surpreendente proximidade com Wittgenstein e tematizar a estrutura aplicativa da compreensão, via seu conceito fulcral de fusão de horizontes:

a estrutura aplicativa da compreensão [...] certamente não significa uma limitação da vontade "não condicionada" de entender o que diz um texto em si, nem tampouco permite que alienemos o texto de seu "próprio" sentido para torná-lo servil a intenções pré-concebidas. A reflexão apenas revela as condições sob as quais ocorre a compreensão num dado momento, as quais já estão sempre em aplicação - na forma de nosso entendimento prévio - quando nos empenhamos em compreender um texto. [...] Pelo contrário, a hermenêutica filosófica chegará à conclusão de que a compreensão só é possível porque aquele que compreende traz consigo seus próprios condicionamentos. A contribuição produtiva do intérprete pertence de um modo inelutável ao sentido do compreender em si. [...] Intérprete e texto têm seus respectivos "horizontes" e [...] qualquer compreensão representa uma fusão desses horizontes [...]. A condição básica para a mediação dessas distâncias é a linguagem, na qual o intérprete (ou tradutor!) expressa o compreendido de modo novo. Teólogos e poetólogos falam aqui do evento linguístico. [...] Por seu próprio caminho, a hermenêutica aproxima-se com isso da filosofia analítica que [...] partiu da crítica neopositivista à metafísica. Desde que não mais se atém à análise das expressões linguísticas e à desambiguação de todos enunciados com o auxílio de linguagens simbólicas artificiais, visando dissolver definitivamente o "enfeitiçamento pela linguagem" [primeiro Wittgenstein], a filosofia analítica não mais pode contornar, como objetivo, o funcionamento da linguagem no jogo de linguagem [segundo Wittgenstein], como mostraram precisamente as Investigações Filosóficas de Wittgenstein. (Gadamer 1997, p. 48-49 [GW2, p. 108-109; destaques e comentários acrescidos])

\footnotetext{
${ }^{4}$ Excerto do livro Des Schweizers Schweiz. Frankfurt a.M.: Suhrkamp, 1977.
} 
Martin Heidegger, professor de Gadamer, já havia explorado esse tópico, afirmando que toda "interpretação explicitante" (Auslegung) apresenta uma tríplice estrutura, composta de "pré-saber" (Vorhabe), "prévisão" (Vorsicht) e "pré-apropriação" (Vorgriff), como explica Jean Grondin (2012, p. 48-49; ver também Schmidt 2012, p. 107-115). A contribuição específica de Gadamer está na ênfase dada ao caráter necessariamente linguístico (ou simbólico) da compreensão, que também é, de modo igualmente necessário, ao mesmo tempo aplicação a determinados objetivos (dimensão pragmática). Mas os projetos diferem em sua natureza: em Heidegger, prevalece a fundamentação ontológica (questão do Ser), ao passo que Gadamer visa a indagação epistemológica (questão do Saber/Conhecer), como salienta Schmidt (2012, p. 165). Wittgenstein, por sua vez, não coloca a questão ontológica e tampouco elabora uma teoria do conhecimento em sua filosofia tardia, o que não significa que seja impossível usá-la para teorizar o conhecimento, como faz Moreno em sua "epistemologia do uso", de caráter pósterapêutico e pragmático. Por isso, entendo que questões tratadas tradicionalmente pela hermenêutica ganharão novos matizes quando abordadas pelo viés de uma tal epistemologia do uso, da prática real.

No texto sobre a perspectiva ameríndia, Martins (2012) cita outros pensadores que compartilham premissas semelhantes em muitos aspectos, como Nietzsche (p. 139, 143) e o próprio Viveiros de Castro (p. 140, 148) autor da pergunta acerca de como pensam os ameríndios sobre aquilo que nos preocupa. Mas, como podemos ter acesso a uma resposta? Na confluência da hermenêutica filosófica com a gramática wittgensteiniana, concluo que partiremos sempre dos nossos parâmetros, por mais que possamos alargar nossos horizontes. E sabendo que o escopo do "nosso" é cada vez mais difícil de delimitar, levando em conta o estágio de interligação da "aldeia global" em que vivemos e os vários lugares que cada um de nós habita (cf. Oliveira 2015a). Mas mesmo a tradução estrangeirizante pressupõe um nós e responderá também a um anseio nosso. Em texto recente (Oliveira 2016, p. 111-112), qualifiquei traduções nessa linha como uma espécie de Uróboro funcional: apontam para a origem, o outro, mas, num nível epistêmico, respondem a uma necessidade própria. 


\section{A irredutibilidade do ato ilocucionário}

Kanavillil Rajagopalan (1992) resenha a pragmática linguística dos anos 1970 e 1980 no tocante às inúmeras tentativas de criar taxonomias que dessem conta do ato ilocucionário proposto por Austin, caracterizando-as como "uma longa história de fracassos" (p. 91). Pergunta então se "haveria algo no próprio conceito do ato ilocucionário que obrigatoriamente frustrasse todo e qualquer esforço classificatório" (p. 92). Propõe, como resposta, "a tese de que o próprio conceito de classes de atos ilocucionários padece de uma incoerência irremediável" (p. 93), desenvolvendo essa tese em três passos, para mostrar que: 1) os esforços classificatórios estão comprometidos com uma concepção atomística do ato de fala; 2) o ato ilocucionário constitui uma unidade irredutível; 3) há uma "incompatibilidade radical entre a irredutibilidade do ato ilocucionário e a meta classificatória que se apoia exatamente no reducionismo atomístico" (p. 93-94). Para nossa discussão, interessa salientar que, caso fosse possível classificar, de modo universal, os efeitos ilocucionários no uso da linguagem, teríamos uma base comum que tornaria perfeitamente exequível traduzir de uma língua a outra no sentido tradicional, de busca pela equivalência na diferença - mesmo quando se traduzisse o radicalmente outro. Mas, nesse caso, o próprio conceito de radicalmente outro cairia por terra.

Rajagopalan (1992) detecta um "etnocentrismo cegamente assumido" na base da "tendência universalizante da teoria dos atos de fala" mainstream da época (p. 118). Reporta também que alguns pesquisadores, em menor número, fornecem evidências contrárias a esse universalismo, quando mostram, por exemplo, que mesmo atos extremamente corriqueiros (para nós), como solicitar algo ou pedir desculpas, estão sujeitos a um enorme número de variações, havendo inclusive casos mais extremos, como "a inexistência, nas línguas aborígenes da Austrália, de verbos correspondentes a 'agradecer' e 'pedir desculpas'” (p. 102). Se imaginar uma língua é imaginar uma forma de vida, então traduzir para essas línguas aborígenes um agradecimento ou pedido de desculpas, tal como os conhecemos, será certamente um bom exemplo da lida com o radicalmente outro - porque esse tipo de comportamento provavelmente não fará parte do repertório dos jogos de linguagem correntes nas formas de vida correspondentes. 
Ainda segundo Rajagopalan (1992, p. 114-116), um gesto reiterado nas tentativas de classificação do ato ilocucionário é o que procura estabelecer um padrão único para atestar sua "felicidade", em "franco atrito com situações concretas de análise". O autor conclui então que todos os casos em tela

\begin{abstract}
parecem apontar numa mesma direção: a hipótese de irredutibilidade do conceito de ato ilocucionário. Isto é, levam à conclusão de que simplesmente não há como reduzir ou decompor um ato em algo que seja de qualquer outra natureza, pois são [os atos ilocucionários] as unidades mínimas da teoria, entes genuinamente êmicos. Sendo unidades diferencialmente estipuladas, a identidade de cada unidade se revela explicável tão-somente em termos de exclusão e, não, como pressupõe a tentativa taxonômica, em termos de positividades. Isso tem diretamente a ver com a questão de "famílias" que [...] o próprio Austin levanta, embora sem se preocupar com um aprofundamento maior nas suas consequências. Ora, são vários os comentaristas que têm observado que a noção da semelhança de família de Wittgenstein aproxima o filósofo austríaco ao estruturalismo de Saussure, cuja pedra angular é precisamente a irredutibilidade das unidades êmicas (Cf. Harris. R., 1988). (Rajagopalan 1992, p. 116-117)
\end{abstract}

Em outras palavras, "ser explicável apenas em termos de exclusão" implica que temos de tomar esses jogos de linguagem na sua relação com o conjunto dos outros jogos que compõe a forma de vida em questão, não sendo trivial transpô-los tal qual para outros contextos. Austin percebera as dificuldades de classificação e aventou a possibilidade de pensar em termos de relações de família, à maneira de Wittgenstein, porém sem assumir as consequências desse conceito, o que significaria "admitir que o máximo que se pode constatar é uma semelhança vaga entre certos elementos do conjunto [...], subvertendo, dessa forma, qualquer esforço taxonômico criterioso e definitivo" (Rajagopalan 1992, p. 112-113).

\title{
VI. A construção do comparável
}

Por mais que a discussão nas últimas décadas tenha enfatizado a diferença e o multiculturalismo, nossos conceitos de tradução permanecem ainda fortemente tributários do pré-requisito da comensurabilidade. Em não havendo comensurabilidade, não há tradução, pois mesmo o conceito de dife- 
rença pressupõe um parâmetro de comparação que permita colocar uma coisa em relação à outra. Abordagens utópicas, que propõem um ideal a ser atingido (qualquer que seja sua formulação), não raro deixam de lado o próprio reconhecimento das diferenças, por vezes radicais, em nome do desejo de que a comunicação entre os diversos seja possível. É isso o que faz Gadamer (1990, p. 406) quando manifesta sua preocupação de que aceitar nossa condição de "exílio" na linguagem implicaria não sermos capazes de compreender uma tradição estrangeira, configurando o que Stanley (2011, p. 824) chamou de "escândalo hermenêutico". A tradução estrangeirizante, ou ética, também ecoa um desejo semelhante, quando propõe o acolhimento do outro. Nada tenho contra esse desejo, ou essa atitude de acolher o diverso - até como possibilidade de crescimento para o que é próprio. Gostaria apenas de advertir para o dilema de querermos fazer isso pressupondo que temos, desde já, acesso ao que é outro. Quando nos propõe uma situação de alteridade radical em que, por exemplo, conversamos com marcianos, Wittgenstein não supõe que a comunicação venha a ocorrer de fato. Não há o deve ético que opõe-se ao "escândalo hermenêutico" de que fala Stanley, ao comentar Gadamer. ${ }^{5}$ Sintomaticamente, a explicação dada por Grondin ao conceito de aplicação de Gadamer vai numa direção diametralmente oposta às propostas de estrangeirização na esteira de Schleiermacher, Venuti e Berman, quando se afirma que:

\footnotetext{
${ }^{5}$ Gadamer e Wittgenstein confluem na aceitação da autoridade da tradição (cf. Schmidt 2012, p. 146148; Wittgenstein 2004, p. 14-15; 23-24 [DC, §§ 93-99; 160-170]), mas seus objetivos são distintos. Gadamer quer investigar o processo de legitimação do saber, para podermos distinguir os pré-conceitos "legítimos" dos "ilegítimos", sem recorrer à distinção iluminista entre "razão" e "autoridade" (Schmidt 2012, p. 148-149). Daí seu conceito de verdade e a pretensão universalista. Em Wittgenstein, tanto o escopo do conceito de verdade quanto o tratamento que lhe é dado são outros. No Tractatus (Wittgenstein 1961 [T]), a análise verifuncional permanece no âmbito estritamente lógico, sendo delegada à ciência a tarefa da "aplicação da lógica". A obra tardia não questiona a legitimação do saber, focando antes a fundamentação do sentido, distinguindo entre norma (uso gramatical) e aplicação (uso descritivo). Essa postura já emergia em 1929: “... continuo a me surpreender com a novidade que é minha forma de filosofar, e por isso preciso tantas vezes me repetir. [...] Esse método é basicamente a passagem da questão da verdade para a questão do sentido" (CV, p. 3). Por outro lado, há uma preocupação com a adequação, visando evitar que características do modelo sejam aplicadas ao objeto em análise: “O objeto de comparação, [...] do qual deriva nossa abordagem, deve nos ser fornecido [.... Sem essa explicitação], tudo o que é verdadeiro para o protótipo da abordagem passaria nolens volens a ser afirmado também do objeto em estudo, e afirmaríamos: 'deve sempre...'" (CV, p. 21). Critica-se aqui a aplicação dogmática do modelo à realidade (atitude que prefere "pensar" hipoteticamente a "descrever" o uso real na linguagem). O trecho remete a Spengler e está na origem do conceito de semelhanças de família (cf. IF, § 66).
} 


\begin{abstract}
A tradução oferece um belo exemplo daquilo que Gadamer entende por aplicação: traduzir um texto é fazê-lo falar em outra língua. Claro que os recursos de nossa língua são então aplicados. O sentido estrangeiro só pode ser vertido para outra língua se formos capazes de entender. Ao transpor o sentido para outra língua, o texto traduzido vem a se fundir (no melhor dos casos) com aquele que acaba de traduzi-lo. Diante disso, uma tradução é tanto mais bem sucedida quanto não se tem a sensação de estar lendo uma tradução. (Grondin 2012, p. 74-75)
\end{abstract}

O impasse se desfaz se aceitarmos que a aplicação ocorre no nível epistêmico, enquanto condição de possibilidade de qualquer compreensão, mas que isso não implica que essa compreensão e, sobretudo, sua rearticulação na nossa língua, nossa forma de vida, dê conta de tudo aquilo que estava articulado no texto original, sobretudo no que the for irremediavelmente êmico, característico daquela outra forma de vida. Para dar conta dessa alteridade, a tradução poderá, em seu nível funcional, apontar para ela, destacá-la, exatamente como sugerem as propostas de estrangeirização, ou de acolhimento do outro, por oposição ao elogio de Grondin à tradução dita "transparente", no sentido tradicional. Compreender o "outro" significa, aqui, perceber ao menos que não é igual a "nós"; que é, em alguns aspectos, irredutivelmente diferente. O próximo passo seria verificar como opera essa diferença, quais são suas regras internas. Tudo isso sem invalidar a percepção, epistêmica, de que qualquer nova compreensão se dará sempre através de um processo de apropriação ou, nos termos de Gadamer, de expansão de nossos horizontes em direção ao alheio (mas sempre com um pé plantado no nosso). ${ }^{6}$

\footnotetext{
${ }^{6}$ Gadamer sugere que "'é literalmente mais correto dizer que a linguagem nos fala, em vez de que nós a falamos'" (VM, p. 463, citado em Schmidt 2012, p. 176). Em outras palavras, "o que pode ser compreendido, o que significa que podemos pensar sobre ele e compreendê-lo interpretativamente, ocorre dentro da linguagem e é limitado por ela" (Schmidt 2012, p. 180). Uma tal limitação já fora formulada pelo jovem Wittgenstein no célebre adágio do Tractatus: “Os limites da minha linguagem significam os limites do meu mundo" ( $T, \S 5.6)$. Cabe levar às últimas consequências as implicações desses insights, quando tratamos da tradução do radicalmente outro. Nesse sentido, a tradução entre línguas, sobretudo aquela que envolver a alteridade radical, será "também [e necessariamente] tradução de ou entre formas de vida (tanto nos limites quanto nas possibilidades)", fornecendo assim uma resposta positiva à indagação de Helena Martins (2014, p. 228) já citada mais acima [comentário acrescido]. Isso não invalida o célebre postulado de Jakobson, segundo o qual o que diferencia uma língua de outras é o que elas têm necessariamente de formular, e não o que seriam capazes de formular - pois toda língua seria
} 
Em trabalhos recentes (Oliveira 2013a-b, 2015a-b, 2016), venho repetidamente lembrando que Paul Ricœur propõe, em suas conferências tardias Sobre a tradução, uma fórmula que pode dar conta do aparente impasse da incomensurabilidade. Comentando situações que poderíamos caracterizar como um discurso sobre o radicalmente outro (descrição do idioma chinês usando categorias que nele inexistem), ou mesmo práticas históricas de tradução, como as de Lutero, Ricœur fala da tradução como construção do comparável (Ricœur 2011, p. 68). Por essa via, a tradução não depende da comensurabilidade entre línguas e formas de vida para operar. Pelo contrário, ela estabelece, pelo próprio ato tradutório, a possibilidade da comparação, de procurarmos entender uma coisa nos termos da outra, sem que isso necessariamente leve a um achatamento das diferenças. Pode-se aqui inclusive proceder à análise pela via do reconhecimento de semelhanças de família, mais vagas ou mais evidentes, seja no trato de conjuntos de traduções num determinado período, como faz Lenita Esteves (2014), ou como opera Gideon Toury (2012, p. 97-98; 203-221) com relação a diversas traduções do mesmo texto, ao longo do tempo. No processo da tradução, as comparações propostas colocam em prática, num certo sentido, aquilo que Wittgenstein chamou de ver como e perceber aspectos. A eventual semelhança, ou diferença, ou equivalência, se aceita como tal, não é necessariamente dada, mas sim construída ao longo do processo.

Em sua discussão do problema tradutório, Toury (2012, p. 35-46) opera com diferentes níveis: o PROBLEMA1 diz respeito à [in]traduzibilidade (abstrata), que podemos situar no nível epistêmico; o PROBLEMAz à dimensão do produto e o PROBLEMA3 ao processo. Quando afirma que não há SOLUÇÃO1 para o PROBLEMA1, Toury reconhece que a tradução não pode ser reduzida a equivalências dadas a priori, mas aceita equivalências práticas, estabelecidas, que dão sustentação a seu conceito fulcral de norma tradutória (cf. Oliveira 2015a, 2016). Além de serem algo estabelecido, resultado de um ato tético, tais normas também mudam com o tempo (como o leito do

capaz de formular o que for dito em outra. Pelo contrário: essa conclusão simplesmente agrega explicitamente o conceito e as dimensões da(s) forma(s) de vida à proposta derridiana de que deveríamos abandonar a ideia de tradução como identidade, em prol de sua compreensão como transformação regulada (de uma língua pela outra, de um texto pelo outro). 
rio que se desloca, na metáfora de Da certeza). Isso pode parecer estranho, à primeira vista, ou para um público leigo, mas corresponde à experiência que temos quando cotejamos diferentes traduções do mesmo texto feitas ao longo do tempo, como mostram vários estudos feitos nas últimas décadas. Wittgenstein, uma vez mais, pode nos ajudar a compreender como isso ocorre:

\footnotetext{
Da compreensão pela linguagem faz parte não apenas um acordo nas definições, mas também (por estranho que pareça) um acordo nos juízos. Isso parece abolir a lógica, mas não o faz. - Uma coisa é descrever os métodos de medição, uma outra é obter e exprimir os resultados da medição. Mas aquilo que chamamos de "medir" é determinado também por uma certa constância nos resultados. (IF, § 243)
}

Resultados relativamente constantes na tradução de certos termos, expressões ou trechos maiores (tipos de texto etc.) indicam que determinadas soluções, propostas inicialmente de modo ad hoc em situações específicas, ganharam aceitação geral e passaram a ser usadas como parâmetro, tornaram-se normas, no sentido de Toury (cf. leito do rio). Tais normas têm validade num certo escopo espaço-temporal, podendo deslocar-se do centro do sistema para sua periferia ou vice-versa (cf. Toury 2012, p. 77). Há certamente fatores históricos e sociológicos que fornecem parâmetros explicativos adequados para descrever tais mudanças, e é sobretudo neles que Toury centra sua atenção. Por outro lado, há também uma dimensão epistêmica, estreitamente vinculada à concepção de linguagem mobilizada nas tentativas de compreender tais processos. Nos desdobramentos que tem procurado dar à terapia filosófica do último Wittgenstein, Arley Moreno aprofunda com muita propriedade a questão colocada na citação anterior e fornece pistas sobre como chegar a uma tal compreensão sem necessariamente findarmos em aporias ou paradoxos (como aquele que versa sobre a [in]traduzibilidade):

\footnotetext{
A descrição do uso mostra que [...] a significação [...] não se reduz à definição a priori do sentido, mas diz respeito ao conjunto de suas aplicações. [...] A definição de uma regra de sentido não permite sempre a antecipação, pelo puro pensamento, de todos os casos de sua aplicação, e tampou-
} 


\begin{abstract}
co proíbe aplicações que venham a exprimir critérios diferentes. Assim, na relação analítica, o pensamento do sentido se exprime na aplicação, e não in vitro, sendo dado que o sentido não é independente da aplicação que dele se faz [...]. Em não sendo as aplicações jamais inteiramente previsíveis, abre-se um espaço cuja exploração poderá trazer novas informações. (Moreno 2012, p. 64-65)
\end{abstract}

Assim, novos usos podem ser introduzidos no lugar dos antigos, seja como variação na aplicação da definição a priori do sentido dessa norma de uso, seja como expressão de critérios diferentes, que emergem justamente em função de alterações no contexto de aplicação da mesma descrição de sentido (como também muda o leito do mesmo rio, na metáfora de Da certe$z a$ ). Por dizer respeito ao funcionamento dos conceitos na linguagem (tout court: sua gramática), num nível muito básico, ou profundo (onde Wittgenstein sugere que coloquemos nossos pontos de interrogação, como citado acima), o raciocínio certamente também é válido para os sentidos que atribuímos tanto a nossos conceitos sobre a tradução como às soluções tradutórias que encontrarmos e suas relações com as normas tradutórias (no sentido de Toury). A própria noção de conceito perde a rigidez que tem na tradição científica e filosófica, motivo pelo qual apreender conceitualmente a noção de forma de vida não significa aqui "aplacar sua inquietude" - como seria nos casos descritos por Martins (2014) ou na apropriação cientificista de Austin por Searle e tantos outros, como mostra Rajagopalan (1992). Por essa via pragmática, ou da epistemologia do uso, talvez fique mais fácil compreender, por exemplo, que tipo de relação se estabelece entre os três tipos de problemas tradutórios elencados por Toury (2012, p. 35-46), ou de que maneira se constrói o comparável na nossa relação com o radicalmente outro, seguindo o mote de Ricœur (2011, p. 68). É nesse sentido que caminha a epistemologia do traduzir que se coloca em meu horizonte de pesquisa, transitando por questões aparentemente díspares, mas voltando sempre aos mesmos tópicos. Se ela puder ajudar a dissolver um ou outro problema nos estudos da tradução, terá cumprido seu papel. 


\section{Referências}

EICHHEIM Hubert, BOVERMANN, Monika, TESAŘOVÁ, Lea, HOLLERUNG, Marion. Blaue Blume. Campinas: Editora da Unicamp, $2011^{2}$. ESTEVES, Lenita. Atos de tradução. Éticas, intervenções, mediações. São Paulo: Humanitas, 2014.

GADAMER, Hans-Georg. Wahrheit und Methode. Tübingen: Mohr, 1990. (6 edição. $=$ Verdade e Método [VM])

GOETHE, Johann Wolfgang von: Fausto. Uma tragédia. Primeira parte. São Paulo: Editora 34, 2010. (Tradução: Jenny Klabin Segal. Notas de rodapé e comentários: Marcus Vinícius Mazzari)

GRONDIN, Jean. Hermenêutica. São Paulo: Parábola, 2012. (Tradução: Marcos Marcionilo. Título original: L'Herméneutique. Paris: PUF, 2008²)

MARTINS, Helena. Tradução e perspectivismo. Revista Letras n. 85, p. 135149, jan./jun. 2012. Curitiba: Editora UFPR.

A tradução e o (silencioso) devir das formas de vida. In L. Esteves; V. Veras (Org.): Vozes da tradução. Éticas do traduzir, p. 221-236. São Paulo: Humanitas, 2014.

MORENO, Arley. Introdução a uma pragmática filosófica. Campinas: Editora Unicamp, 2005.

La description grammaticale et sa fonction transcendantale. In A. Moreno; A. Soulez (Org.): Grammatical ou transcendantal? Cahiers de Philosophie du Langage, vol. 8, p. 43-71. Paris: L'Harmattan, 2012.

Apontamentos para uma epistemologia do uso. Salvador: Quarteto, 2013.

MOYAL-SHARROCK, Danièle. Understanding Wittgenstein's On Certainty. Nova York: Palgrave MacMillan, 2007.

MOYAL-SHARROCK, Danièle; BRENNER, W. H. (Ed.): Readings of Wittgenstein's On Certainty. Londres: Palgrave MacMillan, 2007.

OLIVEIRA, Paulo. Quadro de referência e tradução: Schleiermacher e a hermenêutica à luz do Wittgenstein tardio. In A. Moreno (Org.): Wittgenstein e a epistemologia. Campinas: CLE/Unicamp. 2013a, p. 247-272. (Coleção CLE vol. 63). 
Mainstays for a translation theory on Wittgenstein's line. 36th International Wittgenstein Symposium in Kirchberg am Wechsel. Papers. Neulengbach: Austrian L.-W. Society, 2013b, p. 291-293.

Translation, Sprache und Wahrnehmung. Pandaemonium Germanicum v. 18, n. 25, Jun. /2015a, p. 91-120.

Relative but real and binding: how family resemblance and normative use have found their way into Translation Studies (TS). 38th International Wittgenstein Symposium in Kirchberg am Wechsel. Papers. Neulengbach: Austrian L.-W. Society, 2015b, p. 224-226.

Language conception and translation: from the classic dichotomy to a continuum within the same framework. In T. Seruya; J. M. Justo (Ed.): Schleiermacher revisited: Contemporary readings of On the Different Methods of Translating. Berlim: Springer, 2016, p. 105-114.

PRADO JR., Bento. Erro, ilusão, loucura. São Paulo: Editora 34, 2004.

RAJAGOPALAN, Kanavillil. A irredutibilidade do ato ilocucionário como fator inibidor do êxito das tentativas taxonômicas. DELTA v. 8, n. 1, p. 91133, 1992.

RHEES, Rush. Wittgenstein's On Certainty. There - Like Our Life. Oxford: Blackwell, 2005. (Edited by D. Z. Phillips)

RICCEUR, Paul. Sobre a tradução. Belo Horizonte: UFMG, 2011. (Tradução: Patrícia Lavelle. Original: Sur la traduction. Bayard, 2011)

SCHMIDT, Lawrence. Hermenêutica. Petrópolis: Vozes, 2012. (Tradução: Fábio Ribeiro. Original: Understanding Hermeneutics. Acumen, 2006) SCHULTE, Joachim. Within a System. In Moyal-Sharrock; Brenner (Ed.): Readings of Wittgenstein's On Certainty. Londres: Palgrave, 2007, p. 59-75.

STANLEY, John. Translation Hermeneutics and the Notion of Language Games: A New Paradigm for Synthesizing the Pragmatic and Cultural Turns in Translation Studies? In P. A. Schmitt; S. Herold; A. Weilandt (Hg.): Translationsforschung. Tagungsberichte der LICTRA, IX. Leipzig International Conference on Translation \& Interpretation Studies, 19.-21.5.2010, Teil 2. Frankfurt: Peter Lang. TOURY, Gideon. Descriptive Translation Studies - and beyond. Amsterdam \& Philadelphia: John Benjamins, 2012. (Revised edition) WITTGENSTEIN, Ludwig. Tractatus logico-philosophicus. London: Routledge \& Kegan Paul. The Humanities Press: New York. 1961 (1ª edição: 1922 [T]) 
Über Gewissheit $=$ On certainty. London: Blackwell, 2004 ${ }^{15} .\left(15^{\mathrm{a}}\right.$ edição. Editor: Rush Rhees. $=$ Da Certeza $[\mathrm{DC}])$

Culture and Value. A Selection from the Posthumous Remains. London: Blackwell, 20069 (9ª edição, bilíngue: inglês/alemão. Editor: G. H. von Wright, em colaboração com Heikki Nyman. Revisão do texto: Alois Pichler. Tradução para o inglês: Peter Winch. = Cultura e Valor [CV])

Philosophische Untersuchungen = Philosophical Investigations.

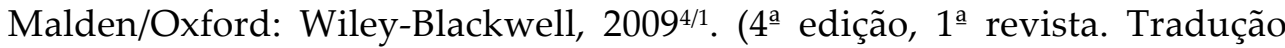
para o inglês: G. E. M. Anscombe, P. S. M. Hacker \& J. Schulte. = Investigações Filosóficas [IF])

Resumo: Discute-se aqui a filosofia da linguagem do Wittgenstein tardio, a partir dos insights epistêmicos de Da certeza e do conceito "forma(s) de vida", no que diz respeito a suas implicações para a teoria da tradução. Sugiro que questões tradicionalmente tratadas pela hermenêutica ganham novas dimensões quando abordadas por esse prisma.

Abstract: This paper discusses the philosophy of language from the later Wittgenstein, through the epistemic insights of On Certainty and the concept of "form(s) of life", with regard to their implications for translation theory. I suggest that issues traditionally investigated by hermeneutics acquire new dimensions when approached in this light. 